\title{
Aerococcus Urinae: A rare cause for multi-valve endocarditis
}

\author{
Jaya D Bathina*, Kasaiah Makam, Robin Horn and Sandra Weiss \\ Department of cardiology, USA
}

*Corresponding author: Jaya D Bathina, Department of Cardiology, 4755 Ogletown-stanton road, Newark, DE 77030, USA.

To Cite This Article: Jaya D Bathina, Kasaiah Makam, Robin Horn, Sandra Weiss. Aerococcus Urinae: A rare cause for multi-valve endocarditis. Am J Biomed Sci \& Res. 2019 - 2(1). AJBSR.MS.ID.000568. DOI: 10.34297/AJBSR.2019.02.000568

Received: January 11, 2019 | Published: March 22, 2019

Keywords: Aerococcus Urinae; Aerococcus Endocarditis; Multivalve Endocarditis

\section{Case Report}

A 42-year-old male with a history of chronic nephrolithiasis presented to the hospital after neighbors found him unconscious at home. On initial evaluation, he was febrile (38.9) with blood pressure of $120 / 104 \mathrm{mmHg}$. He was severely hypoxic with a sinus rate of 90 beats/minute. His examination revealed multiple abrasions, and he was minimally responsive with a holosystolic murmur at the apex. His electrocardiogram showed normal sinus rhythm with no acute ST-T wave changes. Laboratory data revealed a white cell count of $17.4 / \mathrm{hl}$, platelet count of $109 / \mathrm{nl}$, lactate level of $4.8 \mathrm{mmol} / \mathrm{l}$ and creatinine of $1.57 \mathrm{mg} / \mathrm{dl}$. Computed tomography of the head revealed multiple regions of acute infarction involving the right inferior cerebellum, left occipital lobe with mass effect on the left occipital horn. He underwent a transthoracic echocardiogram that showed vegetations on both the mitral and aortic valve. He underwent a trans-esophageal echocardiogram, which demonstrated multiple vegetations on the mitral (Figure 1), aortic (Figure 2) and pulmonic valves (Figure 3) with severe pulmonic, mitral and aortic insufficiency (Figure 4 \& 5). Despite negative urine cultures, serial blood cultures grew Aerococcus urinae and he was given appropriate IV antibiotics. He was evaluated for possible valvular surgery and was deemed to be a poor surgical candidate. He later developed splenic and renal infarcts followed by significant hemodynamic instability requiring vasopressors and ultimately succumbed to his illness after he developed multi organ failure and disseminated intravascular coagulation.

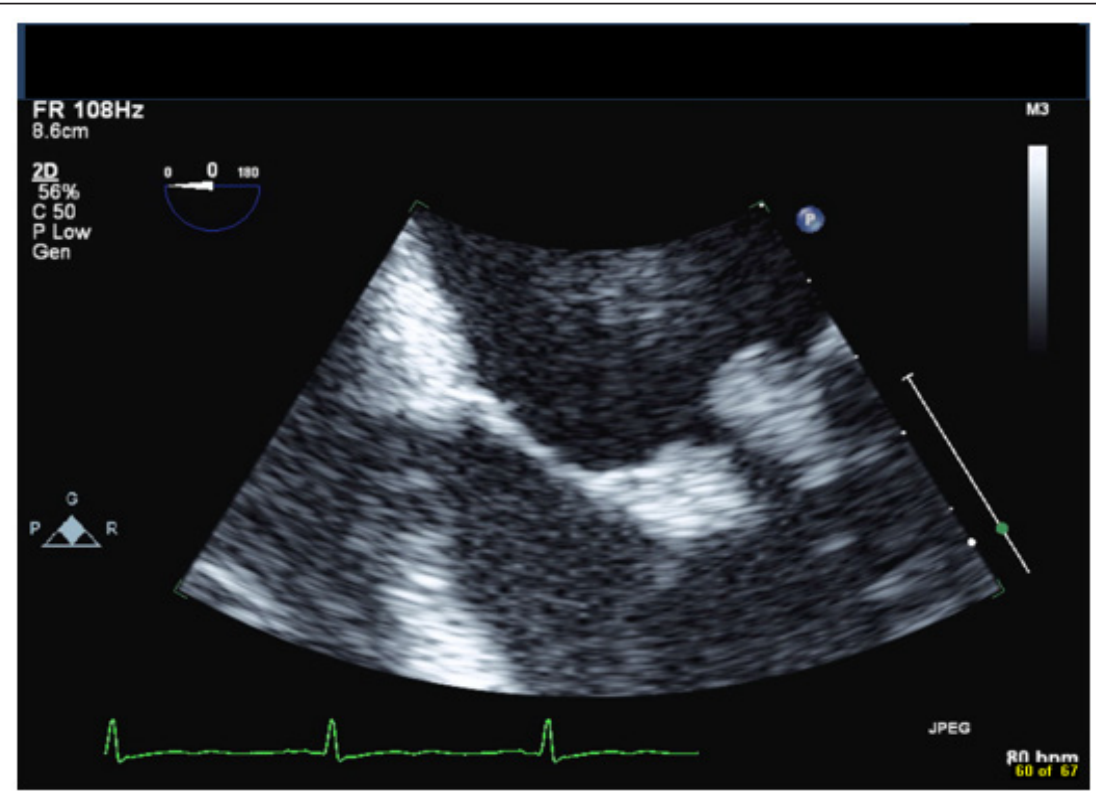

Figure 1: Mitral Veg. 

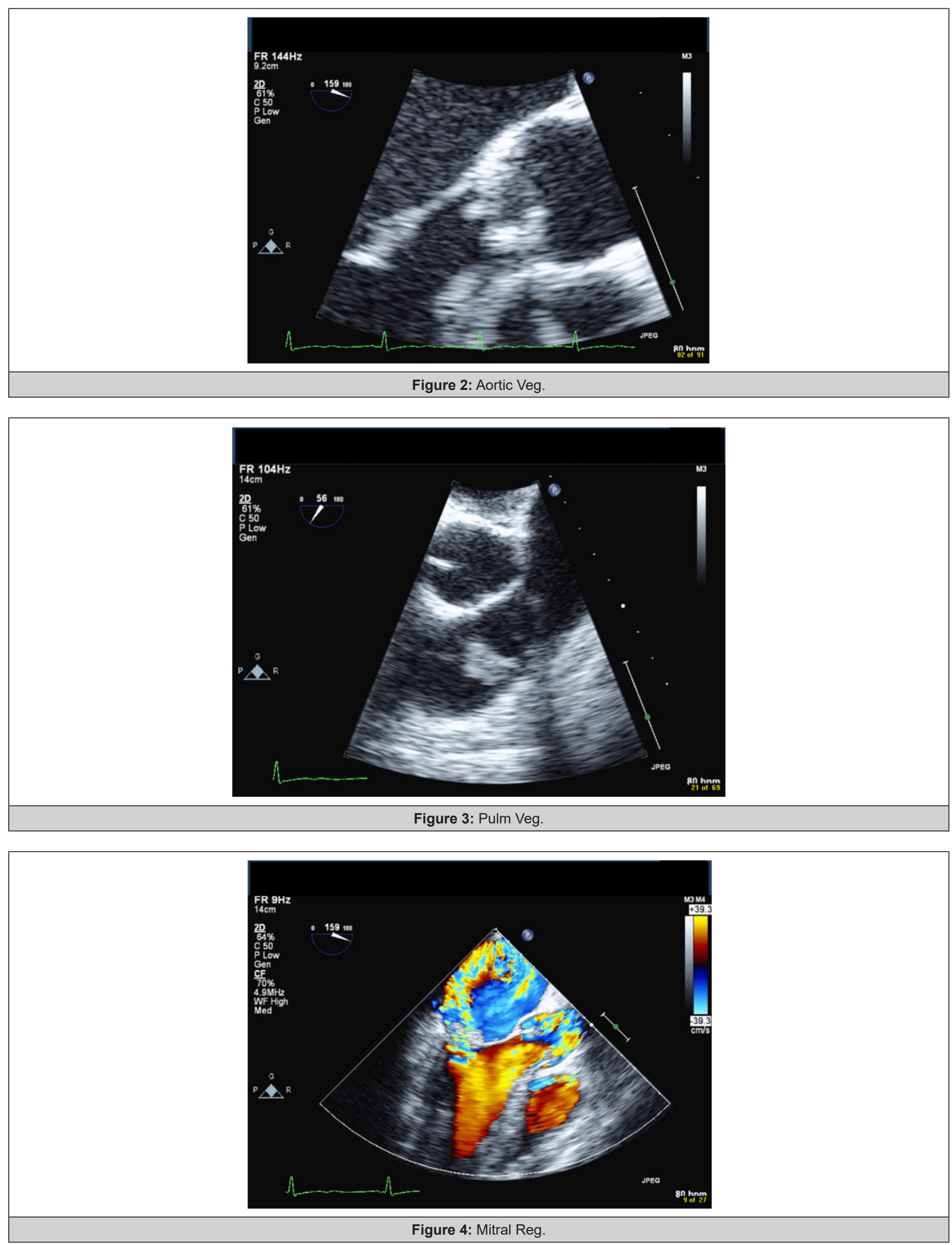


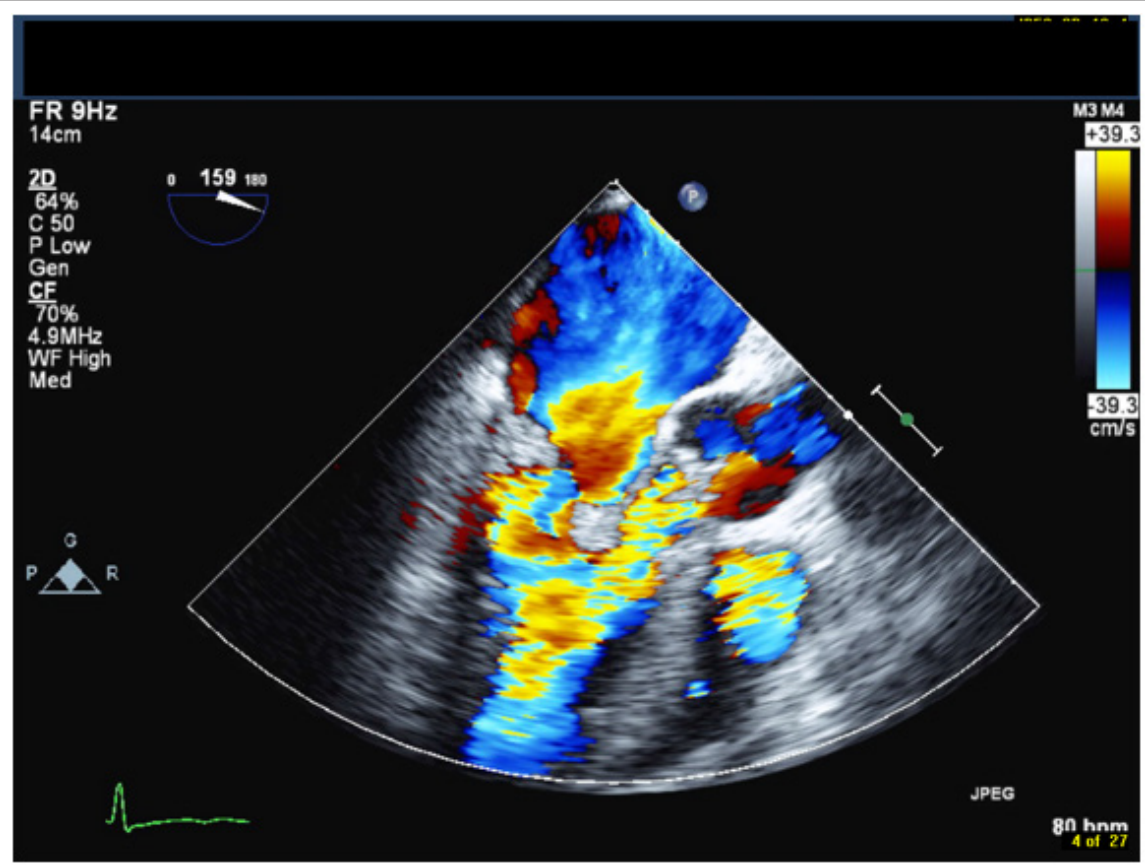

Figure 5: Aortic Reg.

\section{Discussion}

A.urinae was first identified in 1991 as a causative organism for endocarditis [1]. Since then, a total of twenty-three cases (including our patient) of $A$. urinae endocarditis have been reported in the literature to date (Table 1). Aerococci are gram-positive cocci that morphologically resemble staphylococci but have biochemical and growth characteristics of streptococci and enterococci [9]. A. urinae has preponderance in patients with underlying urinary tract pathologies and are reported to be found in 0.3 to $0.8 \%$ of urine samples. The incidence of $A$. urinae bloodstream infection is estimated to be 3 per 1,000,000 per year, as reported by a hospital which serves a 500,000 population. The organism is considered to be of low pathogenicity and may not always need to be treated. Sometimes this organism may initially be dismissed as a contaminant in clinical cultures from non-sterile sites. However, underdiagnoses of this organism can lead to disastrous outcomes [13].

Table 1: List of all of the cases of Aerococcus endocarditis published since 1992.

\begin{tabular}{|c|c|c|c|c|c|c|c|c|c|}
\hline Age & Sex & $\begin{array}{c}\text { Underlying } \\
\text { Urological problems }\end{array}$ & $\begin{array}{c}\text { Predisposing } \\
\text { valvular disease }\end{array}$ & $\begin{array}{l}\text { Valves } \\
\text { involved }\end{array}$ & $\begin{array}{c}\text { Initial } \\
\text { Symptoms }\end{array}$ & $\begin{array}{c}\text { Blood } \\
\text { cultures } \\
\text { +ve or -ve }\end{array}$ & Complications & Survived & Ref \\
\hline 81 & M & Prostate cancer & - & - & - & $+\mathrm{ve}$ & $\begin{array}{l}\text { MI and embolic } \\
\text { complications }\end{array}$ & No & [1] \\
\hline 73 & M & BPH/TURP & - & Aortic valve & Fever & $+\mathrm{ve}$ & Hemiplegia & No & [2] \\
\hline 78 & M & Nephrolithiasis & - & - & - & $+v e$ & None & Yes & [2] \\
\hline 55 & $\mathrm{~F}$ & - & - & $\begin{array}{l}\text { Mitral and } \\
\text { aortic valve }\end{array}$ & $\begin{array}{l}\text { Fever and } \\
\text { back pain }\end{array}$ & $+v e$ & $\begin{array}{c}\text { Cardiac } \\
\text { complications }\end{array}$ & No & [2] \\
\hline 78 & M & - & - & - & - & $+v e$ & MI, Renal failure & No & [3] \\
\hline 89 & M & $\begin{array}{l}\text { TURP/suprapubic } \\
\text { catheter }\end{array}$ & $\begin{array}{l}\text { Degenerative } \\
\text { mitral valve } \\
\text { disease }\end{array}$ & - & - & $+\mathrm{ve}$ & Unknown & No & [4] \\
\hline 81 & M & - & Aortic stenosis & - & & $+\mathrm{ve}$ & MI & No & [5] \\
\hline 43 & M & - & - & - & - & $+\mathrm{ve}$ & $\begin{array}{c}\text { Septic } \\
\text { embolization, MI }\end{array}$ & No & [6] \\
\hline 48 & M & - & - & - & - & $+\mathrm{ve}$ & Hemisyndrome & Yes & [7] \\
\hline 79 & $\mathrm{~F}$ & - & $\begin{array}{c}\text { Aortic } \\
\text { insufficiency }\end{array}$ & - & - & $+v e$ & CVA & Yes & [7] \\
\hline 75 & M & $\begin{array}{l}\text { BPH/Suprapubic } \\
\text { catheter }\end{array}$ & - & Aortic valve & Fever & $\begin{array}{l}\text {-ve Blood } \\
\text { cultures/+ve } \\
\text { PCR of aortic } \\
\text { valve }\end{array}$ & $\begin{array}{c}\text { Septic } \\
\text { embolization }\end{array}$ & Yes & [8] \\
\hline
\end{tabular}




\begin{tabular}{|c|c|c|c|c|c|c|c|c|c|}
\hline 91 & M & $\begin{array}{c}\text { Urinary cathter, BPH, } \\
\text { Renal cancer }\end{array}$ & - & Aortic valve & Fever & +ve & - & Yes & [9] \\
\hline 96 & M & Urinary catheter & - & Mitral valve & Dysuria & +ve & - & Yes & [9] \\
\hline 86 & M & $\begin{array}{l}\text { Prostate cancer, } \\
\text { Urethral stricture }\end{array}$ & - & Aortic valve & $\begin{array}{c}\text { Fever, } \\
\text { Dysuria }\end{array}$ & +ve & $\begin{array}{c}\text { Septic } \\
\text { embolization }\end{array}$ & Yes & [9] \\
\hline 62 & M & BPH, Urolithiasis & - & $\begin{array}{c}\text { Mitral and } \\
\text { aortic valves }\end{array}$ & - & +ve & Cardiogenic shock & Yes & {$[10]$} \\
\hline 69 & M & - & - & Aortic valve & - & $\begin{array}{c}\text {-ve Blood } \\
\text { culture/+ve } \\
\text { PCR aortic } \\
\text { valve }\end{array}$ & - & Yes & {$[11]$} \\
\hline 68 & $\mathrm{M}$ & BPH & - & - & - & - & - & Yes & [12] \\
\hline 81 & M & Yes & - & Mitral valve & Fever & +ve & Unknown & Unknown & [13] \\
\hline 78 & M & Suprapubic catheter & - & Aortic valve & Sepsis & +ve & Unknown & Unknown & {$[13]$} \\
\hline 87 & $\mathrm{M}$ & Yes & - & Mitral valve & Dyspnea & +ve & Unknown & No & [13] \\
\hline 77 & M & $\mathrm{BPH}$ & - & Aortic valve & $\begin{array}{c}\text { Found } \\
\text { down at } \\
\text { home }\end{array}$ & + ve & $\begin{array}{c}\text { Sepsis/ } \\
\text { Noncardiogenic } \\
\text { pulmonary edema }\end{array}$ & No & {$[14]$} \\
\hline 80 & $\mathrm{M}$ & - & - & Aortic valve & Fever & +ve & Septic emboli & Yes & [15] \\
\hline 42 & M & Nephrolithiasis & - & $\begin{array}{l}\text { Aortic, } \\
\text { mitral and } \\
\text { tricuspid } \\
\text { valves }\end{array}$ & $\begin{array}{l}\text { Found } \\
\text { down at } \\
\text { home }\end{array}$ & + ve & $\begin{array}{c}\text { Septic emboli/ } \\
\text { DIC }\end{array}$ & No & $\begin{array}{l}\text { Present } \\
\text { case }\end{array}$ \\
\hline
\end{tabular}

The clinical presentation for the infection can range from simple urinary tract infections, balanitis, cellulitis or spondylodiscitis [17], to life threatening illnesses such as septicemia [1], endocarditis, [10-16] or peritonitis [19]. Initial presenting symptoms can vary from fever, dysuria, sepsis, dyspnea, alter mental status to back pain in various case reports [18]. Advanced age, male sex and underlying urologic conditions, such as prostatic hyperplasia or chronic nephrolithiasis are risk factors for infection [18]. However, it has been described in young patients without known chronic medical conditions [6,7]. Apart from the above-mentioned risk factors, preexisting valvular dysfunction and systemic comorbidities such as ischemic heart disease, diabetes mellitus and malignancy have been proposed as risk factors for $A$. urinae endocarditis [4-7]. The most commonly involved valve is aortic followed by mitral; rarely the right sided valves are involved as seen in our case [18].

A urinae is a gram-positive, microaerophilic, catalase-negative, alpha-hemolytic coccus, growing predominately in tetrads and clusters. In contrast to streptococci, it is capable of growing in $6.5 \%$ $\mathrm{NaCl}$. Its growth on 5\% sheep-blood agar depends on incubation in carbon dioxide. Therefore, growth on urine-dipslide agar is not reliable and, as in our patient, blood cultures may be positive in the setting of negative urine cultures. Though correct identification of A. urinae with biochemical methods is possible, sequencing of the 16S rRNA gene remains the confirmatory test for identification. Although generally indistinguishable from endocarditis caused by other bacterial agents, one distinguishing feature is the relatively high incidence of systemic embolization (55\% vs $20-40 \%$ for other microorganisms). It is believed that both platelet activation and biofilm formation participate in the pathogenesis of endocarditis caused by A. urinae [20]. While it is a rare cause for endocarditis it has an associated high mortality rate due to a significant incidence of embolic events. Complications include cardiogenic shock, septic emboli, renal failure, stroke and disseminated intravascular coagulation. Two frequently used antibiotics for urinary tract infections, cotrimoxazole and quinolones, have no or only moderate activity against $A$. urinae which is sensitive to B lactam and aminoglycoside antibiotics. Due to the rareness of $A$. urinae endocarditis, controlled studies are not possible and therefore antibiotic treatment is not standardized. In vitro susceptibilities of 56 isolates showed little inter-isolate variability with low minimal inhibitory concentrations (MIC) for penicillin, amoxicillin, piperacillin, cefepime, vancomycin and rifampicin, but variable MIC for ceftriaxone. Antibiotic therapy for at least 6 weeks is effective in patients with endocarditis who survive the 1 st week of therapy.

\section{Conclusion}

In conclusion, urologic conditions predispose for infections with $A$. urinae. Generally considered to be of low pathogenicity, this microorganism may cause severe bloodstream infections, including endocarditis. The identification of $A$. urinae can be challenging. Late diagnosis of $A$. urinae endocarditis can be devastating; therefore physicians and microbiologists should consider endocarditis in patients when it is isolated from the blood.

\section{References}

1. Christensen JJ, Gutschik E, Friis-Moller A, Korner B (1991) Urosepticemia and fatal endocarditis caused by Aerococcus-like organisms. Scand J Infect Dis 23(6): 717-721.

2. Christensen JJ, Jensen IP, Faerk J, Kristensen B, Skov R, et al. (1995) Bacteremia/septicemia due to Aerococcus-like organisms: report of seventeen cases. Danish ALO Study Group. Clin Infect Dis 21(4): 943947.

3. Kristensen B, Nielsen G (1995) Endocarditis caused by Aerococcus urinae, a newly recognized pathogen. Eur J Clin Microbiol Infect Dis 14(1): 49-51. 
4. Schuur PM, Sabbe L, van der Wouw AJ, Montagne GJ, Buiting AG (1999) Three cases of serious infection caused by Aerococcus urinae. Eur J Clin Microbiol Infect Dis 18(5): 368-371.

5. Skov RL, Klarlund M, Thorsen S (1995) Fatal endocarditis due to Aerococcus urinae. Diagn Microbiol Infect Dis 21(4): 219-221.

6. Gritsch W, Nagl M, Hausdorfer J, Gschwendtner A, Pechlaner C, et al (1999) Septicaemia and endomyocarditis caused by Aerococcus urinae. Wien Klin Wochenschr 111(11): 446-447.

7. Zbinden R, Santanam P, Hunziker L, Leuzinger B, von Graevenitz A (1999) Endocarditis due to Aerococcus urinae: diagnostic tests, fatty acid composition and killing kinetics. Infection 27(2): 122-124.

8. C Ebnöther, M Altwegg, J Gottschalk, JD Seebach, A Kronenberg (2002) Aerococcus urinae Endocarditis: Case Report and Review of the Literature. Infection 30(5): 310-313.

9. E. Senneby, Petersson AC, Rasmussen M (2012) Clinical and microbiological features of bactermia with Aerococcus urinae. Clin Microbiol Infect 18(6): 546-550.

10. Dirk Bruegger, Beiras-Fernandez A, Weis F, Weis M, Kur F (2009) Extracorporeal support in a patient with cardiogenic shock due to Aerococcus urinae Endocarditis. The Journal of Heart Valve disease 18(4): 418-420.

11. Slany M1, Freiberger T, Pavlik P, Cerny J (2007) Culture-negative infective endocarditis caused by Aerococcus urinae. J Heart Valve Dis 16(2): 203205.

12. Tekin A, Tekin G, Turunç T, Demiroğlu Z, Kizilkiliç O (2007) Infective endocarditis and spondylodiscitis in a patient due to Aerococcus urinae: first report. Int J Cardiol 115(3): 402-403.
13. De Jong MF, Soetekouw R, ten Kate RW, Veenendaal D (2010) Aerococcus urinae: Severe and fatal bloodstream infections and Endocarditis. Journal of Clinical Microbiology. 48(9): 3445-3447.

14. Kass Malek, Toye B, Veinot JP (2008) Fatal infective endocarditis due to Aerococcus urinae- case report and review of literature. Cardiovascular pathology 17(6): 410-412.

15. Erwin Ho, Amsel BJ, Stockman B, Walpot J, et al. (2010) A case of Endocarditis due to Aerococcus urinae. J Heart Valve Dis 19(2): 264-266.

16. Christensen JJ, Gutschik E, Friis-Moller A, Korner B (1991) Urosepticemia and fatal endocarditis caused by Aerococcus-like organisms. Scand J Infect Dis 23(6): 717-721.

17. Astudillo L, Sailler L, Porte L, Lefevre JC, Massip P, et al. (2003) Spondylodiscitis due to Aerococcus urinae: a first report. Scand J Infect Dis 35(11,12): 890-891.

18. Christensen JJ, Jensen IP, Faerk J, Kristensen B, Skov R, et al. (1995) Bacteremia/septicemia due to Aerococcus-like organisms: report of seventeen cases. Danish ALO Study Group. Clin Infect Dis 21(4): 943947.

19. Naghibi M, Javaid MM, Holt SG (2007) Case study: Aerococcus urinae as pathogen in peritoneal dialysis peritonitis - a first report. Perit Dial Int 27(6): 715-716.

20. Oonagh Shannon, Matthias Morgelin, Magnus Rasmussen (2010) Platelet Activation and Biofilm Formation by Aerococcus urinae, an EndocarditisCausing Pathogen. Infection and Immunity pp 4268-4275. 